\title{
Bank Strategy when Facing Financial Technology Competition
}

\author{
Dede Suryanto $^{1^{*}}$ \\ ${ }^{1}$ Finance and Banking Laboratory, Vocational Education Program, Universitas Indonesia. \\ *Email: d.suryanto@ui.ac.id
}

\begin{abstract}
The evolution in banking financial technology shifts banking services from traditional transaction services to modern banking services. This breakthrough changes the way in which banking transactions are performed. Banks should thereby rethink their business strategy to compete in the era of technological progress. Business competition in financial technology (FinTech) comprises of start-ups with technological advantages and endless innovative technology-based financial products. On the basis of the analysis of PT. Bank XYZ's strategy case study, considering the business competition for FinTech mastery, a bank conducts business strategy formulation in the four following steps. First, it adapts to FinTech technology advantage. Second, it invests in FinTech start-ups and technological innovations. Third, it completely collaborates with FinTech start-ups. Fourth, it focuses on improving the quality of service in several operational aspects. Further, competitive advantage is obtained through the improvement of service quality by orienting toward the needs and expectations of consumers. When the needs of consumers change with the development of technology, the bank must immediately rethink and redesign its business strategies to adapt with the rapid changes. Hence, the design of a sustainable business strategy through cutting-edge FinTech is a basic need and challenge of the banking industry in this era of the digital economy.
\end{abstract}

\section{Keywords: banking services, business competition, strategy formulation}

\section{Introduction}

The fable of ants fighting against an elephant is popular in Indonesia; it narrates how the ants despite being small and weak are ultimately able to defeat the mammoth strong elephant. This analogy is true in the case of banks as established and experienced institutions, facing start-up companies in Financial Technology (FinTech) competition striving to seize opportunities in the financial services market. If banks are not savvy in this competition, it is feared that they will not only lose market shares but in the long-term the banking business will collapse.

\subsection{Markets and FinTech Development}

FinTech is a term used in the field of financial services for the combination of the latest innovations in technology and finance. Along with the development of FinTech, financial services today are not only required to ease transaction alone. The need for financial services has become a lifestyle and leisure for some people in the world today - these people are commonly known as the "Millennials" (Teja, 2017). They need financial services that can indulge their life, self-esteem, and social status. Some activities that fall into the category of FinTech are lending and borrowing money using peer-to-peer systems, transfers, buying and selling stocks, and other transactions. One of the reasons that FinTech is important for the lifestyles and financial situations of the world community is that it helps the development of new start-ups. Many new start-ups are trying to create innovation in the field of FinTech.

Millennials are the largest generation, representing up to 1.8 billion people. Data from Mastercard show 33 $\%$ of Millennials think that banks will no longer be needed in the future. This is due to the changing nature of the generation, who leads an all-digital life. Millennials, aged 23-36 years old, are more familiar with FinTech than banking because of their familiarity with technology, thus adapting to FinTech faster; hence, conventional banking features are being abandoned (Milne, 2016).

In America, conventional payments via ATMs or going to a bank are unpopular in the eyes of Millennials. Approximately $68 \%$ of them use mobile or desktop to perform various banking transactions. Similarly, on the basis of the data from FinTech Indonesia and Daily Social, only $36 \%$ of adults in Indonesia have accounts in formal financial institutions, while the users of the Internet through smartphones has increased by $70 \%$. The same data also mention the amount of new loans to GDP is $34.77 \%$. This figure reflects the magnitude of the national FinTech market. The FinTech Indonesia Association also notes that only $9 \%$ of people use credit cards 
as payments, and $27 \%$ of people keep their money in banks. There are 49 million SMEs that are not worthy of credit disbursement banking (License to Bill, 2017). This presents a promising market for the future growth of FinTech.

\subsection{Bank Business Nowadays}

Banking and financial markets have been subjected to significant change in the recent decades. In the disruptive technology era, markets have influenced and benefited from dramatic progress in all forms of technological operations including computer hardware and software capabilities; optimization of functionality in circuits and processors; telecommunication speed and efficiency; mobile access, particularly, through mobile phones, tablets, and other hand-held devices and wearables; and substantial reductions in manufacturing and shipping costs (Milne, 2016). In the development of technology in the era of the digital economy, the emergence of innovative FinTech has impacted the financial world-including the banking sector, online payments, cryptocurrency, and e-commerce — which is growing rapidly (Coeckelbergh, DuPont, \& Reijers, 2018). FinTech will thus form an important part of the development of the new digital economy. Digital economy and digital society can be considered as constituting those parts of the economy and society that operate through or that are tied to digital systems - particularly - including the Internet and digital telecommunications. It was estimated that, because in 2015 , the digital economy represented around $22.5 \%$ of the world economy $(\$ 19,159$ billion), it would grow to $25 \%$ by 2020 ( $\$ 24,615$ billion) (Walker, 2017).

Further, banks cannot escape the demands of this era of FinTech development; it is inevitable that banks will have to digitally evolve. Several banks in Indonesia have already started adapting by the means of service innovations that focus on digital services. One way to adapt is for banks to invest in start-ups, helping the pilot businesses to grow and open access to the merchant network and consumers.

Banks have an advantage in FinTech management compared to non-bank FinTech companies because banks have strict access regulations that promote prudential principles to ensure the security of their customers. The use of this technology platform is economical compared to non-bank FinTech companies; however, customers determine which financial services or products can satisfy their needs. This banking regulation is thereby a competitive advantage that is not owned by non-bank FinTech companies.

However, the banks' superiority, e.g., regarding risk management, has led to the development of FinTech mastery lagging far behind the financial service innovations provided by non-bank FinTech companies. Hence, this could lead to consumers utilizing financial services provided by non-bank FinTech companies.

\subsection{Designing Business Strategy}

Banks without information technology support cannot compete in the banking industry, both nationally and internationally. Customers are increasingly critical and careful at choosing quality technology-based bank services, thus making inter-bank competition intense. Banks vie to serve consumers, giving the best customer services with the support of technological sophistication. Improving the quality of bank services encourages banks to offer varied products supported by information technology for customers' convenience and delight in the form of business credit or debit services, direct banking, and so on FinTech companies have simplified and personalized multiple financial services activities for customers-ranging from making mobile payments, transferring money, and getting a loan, to raising funds and managing their assets (Chen, Li, Wu, \& Luo, 2017).

Banks must think more critically to formulate the latest technology-based business strategies and-at the same time-redesign their obsolete banking products. Therefore, banks need to identify the critical factors so that their market shares are not manipulated due to customers' switching to products offered by FinTech companies, as they are more practical, reliable, and easy in application.

\subsection{How Should the Banks Strategize?}

Facing increasingly keen competition in this era of FinTech, banks need to possess competitive capabilities supported by technological advantages. The competitiveness of banks is closely related with the strategies they develop and perform. However, FinTech makes the banking business process efficient and effective so that banks can record their periodic growth and expansion of the industry's market share. Formulation of a bank 
strategy with FinTech support commences from planning the processes and designing and implementing operational management and risk management.

As FinTech is an important factor in a bank's business strategy, the authors undertook a study to identify important factors in the formulation of FinTech-based business strategies and the implementation of those strategies in the face of banking business competition. This study thus drew on the experience of PT to design a FinTech mastery strategy formula for Bank XYZ that would allow deeper analysis by presenting FinTech growth conditions developed in both the Indonesian and the global market.

\section{Literature Review}

In the past few decades, banking and financial markets have experienced rapid growth. This has led to many advances in, and benefits from, technological operations such as computer hardware and software, data processing speed and efficiency in telecommunications technology, and use of mobile phones and other digital communication devices. These technological advances have led to significant reductions in production and shipping costs (Syaniardi \& Shihab, 2016).

According to Jelassi and Enders (2016), e-business is the use of electronic means to conduct the organization's business internally and externally. Thus, the e-business strategy is the use of electronic-based applications in the organization's operations including products to support the organization's strategy for competitive advantage. Maharjan and Shakya (2015) explained that branchless banking is the use of communication technologies such as cellular phone or the Internet to facilitate financial transactions between banks or parties affiliated with banks (e.g., agents or merchants) and customers without having to go to a branch office of a bank. To gain competitive advantage, the financial industry no longer uses the Internet conventionally. In the era of the digital economy, FinTech has shifted and oriented to optimization and technological innovation, which initially resulted in business models in the financial industry. An example is technologies that improve operations by driving traffic improvements and modularity. This trend leads to better accessibility capabilities, anti-fraud capabilities, and the ability to control details; the most important improvement is that technology has resulted in reduction of risk and cost (Lee, Yen, \& Hurlburt, 2018).

\section{Methodology}

This study was an applied research aimed at obtaining a strategy formulation that can be employed to solve problems within an organization. This study included a case study conducted within a particular organization and aimed to analyze and interpret the strategy within the organization. This research was conducted in one of the largest banksin Indonesia and aimed to formulate business strategy in the face FinTech competition.

A case study approach was employed at one of Indonesia's leading banks, conducting observations of various available information sources, reviewing the literature of various papers, and analyzing the formulation of strategies by FinTech-based banks. The authors further evaluated the bank's strategy for mastering FinTech and related it to the growth of FinTech as a new financial industry both in Indonesian and the global markets.

The relevant data were gathered from the literature and relevant websites. The object of the case study was PT. Bank XYZ Tbk, which is one of the top publicly-traded banks (Hafas, 2016).

In this research, data collection was performed by observation and document review. Observations were conducted on business activities in PT. Bank XYZ Tbk, as reported in various news media such as websites, newspapers, and television. Document review was conducted on several papers about business strategy and FinTech, and business strategy was reviewed and formulated on the basis of the collected data.

\section{Results and Discussion}

The market competition situations for banks today are fierce; banks are faced with a choice of either making FinTech companies their competitors or partners to collaborate with and develop a larger market share. The market in Indonesia is quite large, and, as the population will increase in the next decade, no other alternative seems to prevail for banks other than collaborating with FinTech companies — which are generally start-up companies - as several consumers availing financial services are yet to be reached through bank access 
(unbank). In addition, many innovative bank products still seem to prevail that can be offered to consumers to guarantee their loyalty toward banks.

Competition for financial market share will only drain the funds of the bigger banks for investments. Thus, banks should collaborate and synergize with FinTech companies, strengthen technological aspects by adopting technology owned by FinTech companies, or acquire FinTech companies' business if it can generate profits for both parties. Banks have reliable and tested risk management systems that have encountered various economic conditions. Combining banks' excellence in risk management not owned by FinTech with the advantages of financial technology of FinTech companies can help banks' investment reach wider markets and create innovative bank products that can attract new customers.

The process of formulating a bank strategy refers to several important decisions. First, banks should adapt FinTech technology to strengthen their operational management. Mastery and adaptation to the latest developments in science and technology is a crucial competitive capital in the banking industry. In the banking business process, the mastery of technology strongly supports the bank's operational activities so that it becomes more effective and efficient because it can simplify and control the operational process with a limited number of human resources. Through the mastery of technology, a bank can shorten transaction and credit application submission durations, and transaction processing data can immediately meet the needs of customer transactions. Thus, the quality of services provided to consumers can be improved, by moving data from the application form to system (data entry), thereby analyzing customer data (credit analysis) and delivering cards. A decrease in operational costs can be achieved up to $60 \%$ per application. The technology in the information management system will also facilitate the bank in storing, recording, and analyzing customer data, thus assisting the bank in maintaining customer relationships, better addressing consumer complaints, and developing more suitable products and services for consumers.

Second, banks should invest in FinTech companies for both technological innovation and open access to wider merchant and consumer networks. For example, PT. Bank XYZ launched "XYZ" Capital, which is a venture capital company that will target entrepreneurs or innovative start-ups. In addition, PT. Bank XYZ also held the event "Mandiri Technopreneur," a competition for young "technopreneurs" who aim to capture the latest ideas and solutions in FinTech. Interestingly, the winners of Mandiri Technopreneur are then fostered in Mandiri Business Incubator. Mandiri Capital will be thereby providing investment opportunities to participants who successfully complete the incubation program. A successful example is e-cash; by initially investing in a start-up, they managed to reach a certain commercialization stage, thus attaining more investments.

Third, banks should completely collaborate with the FinTech companies. The bank's strategy to win business competition through FinTech mastery is conducted by providing excellent services by using the latest innovative FinTech products and cooperating with FinTech companies to create FinTech-based products. In creating innovative financial services products, a factor that needs to be considered is the intention to use. In addition, establishing synergy between the FinTech and bank industries require the following.

Banks must collaborate on information paths by utilizing large customer data and distribution channels that have been constructed. The utilization of FinTech function is thereby expected to improve bank efficiency.

Banks must collaborate to create products that become solutions for consumers. For this, FinTech companies with banks and financial institutions need to design products (building product) that are useful for both the parties. For example, this synergy can be attained by a core bank for SMEs with a FinTech company that provides a digital SME platform.

Fourth, banks should focus on improving the quality of service, human capital, bank operations, etc. Banks must also evaluate how their business processes have been conducted so far, including how consumers respond to the quality of bank services, the competencies and progress of employees in each period, the quality of the whole process of bank operations and management, the application of technology vs. manual processes, and whether the bank as a learner organization has grown in organizational maturity in line with its vision and mission.

To face business competition in this FinTech era, PT. Bank XYZ has implemented several business strategies considering various factors that are key to success. Following are the factors on the competition strategy being implemented.

First, regulation of the company can greatly influence what strategy the company will follow. Regulations may be used to protect the service as a monopoly or to impede such a service provider by a foreign party as it does in telecommunications and aviation. Regulations are issued by the government in the form of laws and 
regulations. The purpose of regulation is to establish and maintain harmony and to cooperate and create efficiency in the use of resources. In addition to specialized transactional network services, regulation is required to accelerate the realization of desired systems and prevent or reduce foreign exchange transfers.

Second, qualified human resources are needed in planning, designing, realizing, operating, and maintaining all service activities. High quality human resources are expected to produce good work output.

Third, innovation is the spirit of human resources to always seek new breakthroughs along with the rapid change in information technology.

Fourth, there are differences in the implementation of IS/IT between agencies, such as differences in hardware/software, data/information, or methodologies used. This makes it difficult for transactional network services to be used by other bank customers where there is a real-time online data/information transfer between the systems. Therefore, a standardized procedure agreed upon by all parties needs to be formulated. The need for standardization concerns technical and non-technical issues; technical standardization deals with how one computer can communicate with other computers (interconnectivity), while non-technical standardization is the same system running procedure. Security is required to obstruct and thwart the unauthorized party from accessing, modifying, or damaging data. Data security in this service using a multilevel security system means that the handling of data security is performed in an integrated manner including hardware, software and the user. The levels of security are physical security of the location of the computer from unauthorized people using hardware/software that can interfere with the service and network security of data when transaction data are transmitted through the network. This is conducted by using hardware and software tools that are able to scramble the data so that they cannot be understood by other parties. Only authentic customers or operators can alter the data. It may use special keys, personal identification number, password, or other unique identification tools.

Fifth, commitment here is the seriousness and consistency in organizing it. High commitment to the creation of FinTech-based banking products would provide trust and convenience to the customers who use FinTech-based bank products.

To support innovation in FinTech, banks need strategies to become the best institution and able to dominate the market. Some of them are promoting and rewarding customers as an effort to get people interested in saving at the bank. Conducting development in the field of banking technology can meet the needs of an increasingly widespread society. Banks need to improve their services and convenience to customers, and can offer competitive interest rates. They can open branch offices, auxiliary offices, and ATMs, and offer various kinds of convenience for prospective customers.

\section{Conclusion}

The influence of FinTech development on financial and banking business competition in the era of the digital economy is very sophisticated. Banks that can master the latest FinTech and continue to innovate in the creation of FinTech-based products will have an edge in business competition. Banks must begin to redesign their competitive strategy by promoting the mastery of FinTech in its various business operations. Conversely, banks without the latest FinTech mastery will only be a weak giant and will have to compete with start-up FinTech companies.

On the basis of the case study of PT. Bank XYZ's design of business strategies in FinTech, it can be concluded that banks in the face of the FinTech era have actually become serious regarding designing their competitive business strategies, which focus on improving the quality of bank services to consumers (Aulia, 2017). These business strategies formulate the latest product innovations and collaboration with FinTech companies for the creation of innovative FinTech products. The most important factors developed in designing business strategies include (1) regulation, which is the main factor to encourage banks to cooperate with other related parties; (2) quality of human resources, who plan, design, rehabilitate, operate, and maintain all service activities; (3) innovation, i.e., the spirit of human resource to always seek new breakthroughs along with the rapid change of science and information technology; (4) standardization, i.e., factors to facilitate the handling of technical problems and the determination of the quality of service; and (5) commitment, seriousness, and consistency in organizing these strategies.

While implementing these developed strategies, it is vital for banks to adapt the latest FinTech technology and build business synergy with FinTech companies as follows (1) collaborating on the information path by 
utilizing the data of many customers and distribution channels that have been built, and the utilization of FinTech function is expected to improve bank efficiency; and (2) collaborating to create products that become solutions for consumers; for this, FinTech companies with banks and financial institutions need to design process products that are useful for both the parties - for example - this synergy can be established by a corebased bank for SMEs with FinTech, providing a SME digital platform.

Finally, competitive advantage can be obtained by improvising service quality that is oriented toward the requirements and expectations of consumers. As the needs of consumers change alongside the development of technology, the bank must rethink and design business strategies to adapt to those rapid changes. Therefore, the design of a sustainable business strategy through cutting-edge FinTech is a fundamental need and challenge of the banking industry the digital economy era.

\section{Acknowledgment}

As this paper has several limitations in explaining in depth the formulation of business strategies developed by banks, it seeks criticism and advice from the readers for further refinement. This study would have been impossible without the support of various parties. The authors would thereby like to thank the Vocational Education Program, Universitas Indonesia, for aiding helped and facilitating the authors for constructing the study.

\section{References}

Aulia, A. (2017) Jurus Bank Konvensional Menghadapi Era FinTech dan Milenial https://tirto.id/jurus-bank-konvensionalmenghadapi-era-FinTech-dan-milenial-cvju, hlm. 1.

Chen, Z., Li, Y., Wu, Y., \& Luo, J. (2017). The transition from traditional banking to mobile Internet finance: an organizational innovation perspective - a comparative study of Citibank and ICBC. Financial Innovation, 3(1), 12.

Coeckelbergh, M., DuPont, Q., \& Reijers, W. (2018). Towards a Philosophy of Financial Technologies. Philosophy \& Technology, 31(1), 9-14.

Hafas, R. (2016). https://www.bankXYZ.co.id/corporate01/news-detail.asp?id=QLOH3501525\&row=9. Diakses pada 29 Oktober 2017.

Jelassi, T., \& Enders, A. (2004). Strategies for E-Business, Harlow: Pearson.

Lee, M. R., Yen, D. C., \& Hurlburt, G. F. (2018). Financial Technologies and Applications. IT Professional, 20(2), $27-33$.

License to bill. (2017, June). Financial technology Publication info: The Economist: London, 423(9046), 72.

Maharjan, M., \& Shakya, S. (2015, October). System architecture for social security cash transfer through branchless banking in Nepal. In 2015 International Conference on Green Computing and Internet of Things (ICGCIoT) (pp. 60-64). IEEE.

Milne, A. (2016). Competition policy and the financial technology revolution in banking.

Syaniardi, Y. H., \& Shihab, M. R. (2016, October). Formulating e-business strategy for branchless banking: A case of a bank in Indonesia. In 2016 International Conference on Advanced Computer Science and Information Systems (ICACSIS) (pp. 201-206). IEEE.

Teja, A. (2017). Indonesian Fintech Business: New Innovations or Foster and Collaborate in Business Ecosystems?. The Asian Journal of Technology Management, 10(1), 10.

Walker, G. (2017). Financial Technology Law-A New Beginning and a New Future. The International Lawyer, 50(1) 137215. 